\title{
A Sociolinguistic Perspective of Betawi Adolescents' Attitude towards Mother language
}

\author{
Tadjuddin Noor \\ Faculty of Languages and Literature, \\ National University of Jakarta \\ Dwi Murdiati \\ Faculty of Law, \\ University of Jakarta
}

\begin{abstract}
The research aims to describe the language attitudes of Betawi adolescents towards their mother tongue,. Their attitude towards the influence of the Bahasa language shift to their mother tongue. Ttheir attitudes towards the influence of foreign languages shift to their mother tongue. This is a descriptive, quantitative, and qualitative research, with respondents randomly selected from five Jakarta areas, namely Central, North, West, East, and South. In addition, data were also taken from buffer cities such as Bekasi, Tangerang, and Depok. Data were described and interpreted using Lambert's theory, which stated that attitudes consist of three aspects, namely cognitive (knowledge), affective (assessment), and conative (behavior). Furthermore, the World Health Organization stated that the description and interpretation of adolescents' conception comprises of three criteria: biological, psychological, and socio-economic. The results showed that The language attitude of Betawi adolescents towards their mother tongue was negative. Their attitude towards Bahasa positively shifted their mother tongue, and their attitude towards foreign language negatively shifted their mother tongue.
\end{abstract}

Keywords: Sociolinguistic Perspective, Mother tongue, Attitudes, Betawi, Adolescent

\section{Introduction}

Many experts have carried out several studies on attitudes, especially in the scope of social psychology(Sercombe, 2019). Smith and Triandis stated that attitude is a person's readiness to react to a present situation or event, which is usually associated with mental and behavioral attitudes (Coluzzi, 2011). Anderson reported two types of attitudes, namely linguistic and non-linguistic, relating to language's cognition or beliefs. Therefore, language attitude is a relatively long-term belief that gives a person the tendency to react in any desired way (Giyoto, 2013).

Everyone has a positive attitude toward language (Leng, 1980). However, it can become negative when a person or group of people is influenced by foreigners, especially those with prestige in the political, economic, and socio-cultural fields(Leach 
et al., 2016). This is because they tend to influence speakers of a certain language, either directly or indirectly, making them possess a negative attitude towards their language (Ezhevskaya, 2020; Abdurrahman, 2011). Furthermore, in most cases, speakers of the first language are aware of the numerous advantages associated with the second language, which is usually dominant in economic, political, and social competition. Therefore, in such a situation, one can express a positive view of the second language, aside from its ability to reactively express negative attitudes towards the first language (Kamaruddin in Lukman, 2012). Lambert (1967) stated that attitudes consist of three factors, namely (1) Cognitive aspects relate to knowledge on the environment and the idea of categories used in the thinking process. (2) The affective aspect is associated with the issue of assessing a person's positive or negative attitude towards something, (3) Conative aspects regarding behavior or actions as the final decision of reactive readiness to a situation (Mu'in, 2019).

Generally, the three aspects of attitude are closely related, although, sometimes pleasant or unpleasant experiences makes the relationship incompatible (Slobodaniuc, 2021). However, when these relationships are in line, the behavior can determine attitude and vice versa. Many experts claim that behavior does not necessarily imply attitude (Muniandy et al., 2010). One of the phases of human development in adolescence is associated with the development of physical and socio-psychological maturity, also known as the transition period (Partala \& Kallinen, 2012). According to the World Health Organization (1974), as stated by Sarwono, adolescents have three criteria, which are described as follows: (1) Biological, adolescents are individuals that develop present early signs of maturity until they are sexually matured. (2) Psychological, adolescents experience psychological development and identification from childhood to adulthood. (3) Socio-economic, adolescents experience a transition from fully socio-economic dependence to a relatively independent state (Tanasy, 2019).

In Indonesia, adolescents are youth between the ages of 15-24 years, which is close to the United Nations' limit set. This is also in line with the Central Bureau of Statistics population data that the age range of 15-24 years is equivalent to the age of youths from junior high school to college. Mother tongue is the first language that is mastered and used daily by a person to convey thoughts, feelings, and needs(HoganBrun \& oRourke, 2019). This is also known as the local language and happens when parents communicate with their children in everyday life(Marten et al., 2012). The cultural richness of a nation can be reflected through local languages, however, there is an undeniable fact that its existence is increasingly being neglected (Ferguson, 2019). The Bahasa language that is taught and used as the official language in schools is one reason for the reduced use of the mother tongue by teenagers. English or other foreign languages are considered to have more prestige with commercial value than local languages, which is defined as a way to preserve culture. Betawi people's mother tongue is the Betawi language, which is one of the endangered local languages due to the following reasons: 1) Parents of the Betawi community are no longer accustomed to speaking Betawi to their children. 2) Bahasa has been used massively among the 
Betawi people. 3) The Betawi language is not taught in schools as a local content subject. 4) The efforts to maintain the language by the Jakarta provincial government are only limited to rhetoric and rules, and not yet implemented.

\section{Research Method}

This study aims to describe: 1) the language attitudes of Betawi adolescents towards their mother tongue. 2) their attitude towards the influence of the Bahasa language shift to their mother tongue. 3) their attitudes towards the influence of foreign languages on a shift to their mother tongue.

This is a quantitative and qualitative research with the sociolinguistic approach, used to examine language in society. The random sampling method was used to obtain data from 120 adolescents in five areas of Jakarta, namely Central, North, West, East, and South. In addition, data were also obtained from Jakarta borders such as Bekasi, Tangerang, and Depok areas due to the presence of the Betawi people. The data were collected by submitting a questionnaire which was arranged according to the research objectives. Its questionnaire contains language attitudes based on Lambert's theory, which stated that attitudes consist of three components, namely cognitive (knowledge), affective (judgment), and conative (behavior). The data obtained were analyzed using the PASW Statistics program, which is used to process quantitative descriptive statistics. The data were further analyzed qualitatively by providing descriptions and interpretations.

\section{Discussion}

\section{The attitude of Betawi Youth towards Their Mother Language}

The attitude of Betawi adolescents towards their mother tongue is analyzed based on Lambert's theory (1967), which stated that the attitude consists of three aspects, namely cognitive, affective, and conative.

\section{Cognitive Aspects}

The following shows the results of Betawi adolescents' attitudes towards their mother tongue from the cognitive aspect:

Table 1 Respondents' Answers for the Cognitive Aspects

\begin{tabular}{|c|c|c|c|c|c|c|c|c|c|c|}
\hline $\begin{array}{r}\text { Indicator } \\
\text { Codes } \\
\end{array}$ & Statement & $\begin{array}{l}\mathbf{F} \\
\% \\
\end{array}$ & STS & TS & RR & $\mathbf{S}$ & SS & Total & $\begin{array}{l}\text { Total } \\
\text { Score } \\
\end{array}$ & $\begin{array}{l}\text { Ideal } \\
\text { Score } \\
\end{array}$ \\
\hline \multirow[t]{2}{*}{$K 01$} & \multirow{2}{*}{$\begin{array}{l}\text { Betawi language shows } \\
\text { the identity of the Betawi } \\
\text { people }\end{array}$} & $\mathrm{F}$ & 22 & 72 & 24 & 2 & 0 & 120 & 246 & \multirow[t]{2}{*}{600} \\
\hline & & $\%$ & 18,3 & 60 & 20 & 1,67 & 0 & 100 & 41,00 & \\
\hline \multirow[t]{2}{*}{ KO2 } & \multirow{2}{*}{$\begin{array}{l}\text { The Betawi language is a } \\
\text { means of daily }\end{array}$} & $\mathrm{F}$ & 18 & 56 & 44 & 2 & 0 & 120 & 270 & \multirow[t]{2}{*}{600} \\
\hline & & $\%$ & 15 & 46,7 & 36,7 & 1,67 & 0 & 100 & 45,00 & \\
\hline
\end{tabular}




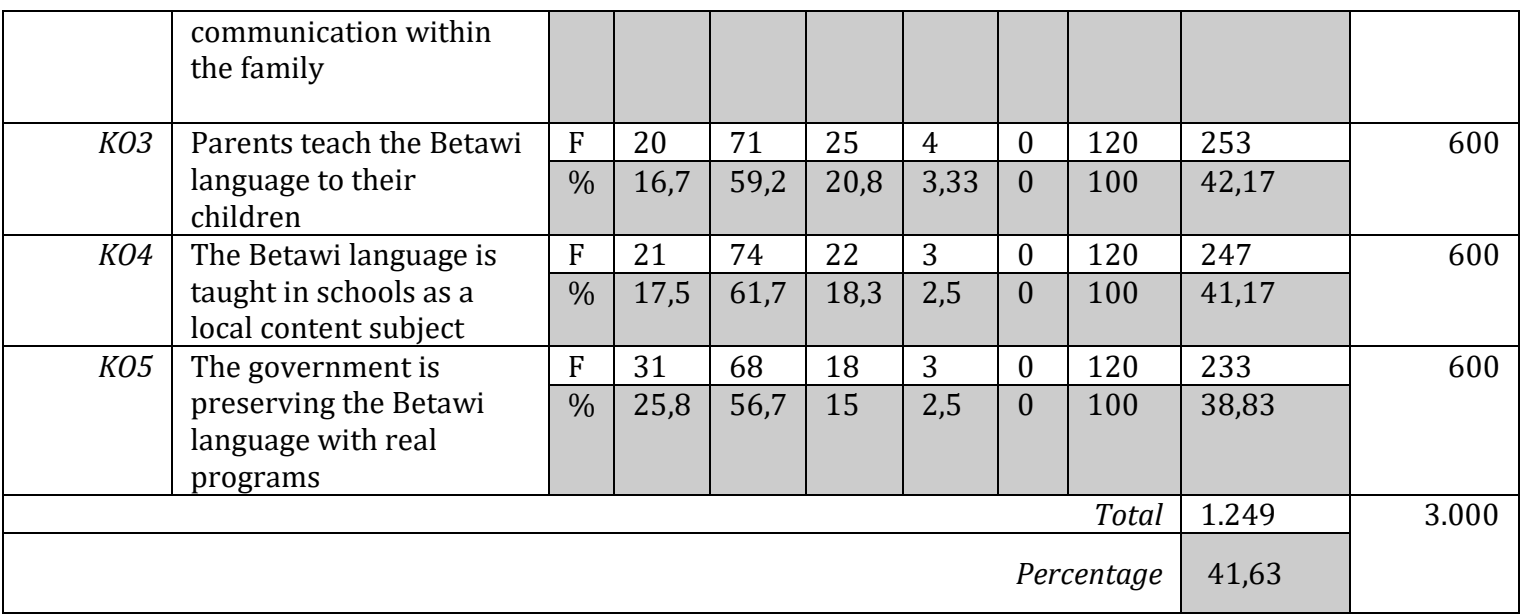

Table 1 shows that the respondents' expected score for answers to the questionnaire statement on cognitive aspects is 3,000, with a total value of 1,249 or $41.63 \%$ of the ideal score. All indicators are below 50\%, with the highest of $45 \%$ assigned to $\mathrm{KO} 2$, indicating that the Betawi language is a means of daily communication in the family. The analysis results showed that the respondents had negative language attitudes on the cognitive aspects, as seen from all indicators showing below $50 \%$. The cognitive aspects related to the knowledge of both Betawi language taught by parents and schools as local content are negative.

\section{Affective Aspects}

The following are the results of Betawi adolescents' attitudes towards their mother tongue from the affective aspect:

Table 2 Results of Respondents' Answers for Affective Aspects

\begin{tabular}{|c|c|c|c|c|c|c|c|c|c|c|}
\hline $\begin{array}{r}\text { Indicator } \\
\text { Codes }\end{array}$ & Statement & $\begin{array}{l}\mathbf{F} \\
\%\end{array}$ & STS & TS & RR & $\mathbf{S}$ & SS & Total & $\begin{array}{l}\text { Total } \\
\text { Score }\end{array}$ & $\begin{array}{l}\text { Ideal } \\
\text { Score }\end{array}$ \\
\hline \multirow[t]{2}{*}{$A F 1$} & \multirow{2}{*}{$\begin{array}{l}\text { I feel proud when } \\
\text { communicating using the } \\
\text { Betawi language }\end{array}$} & $\mathrm{F}$ & 24 & 68 & 25 & 3 & 0 & 120 & 247 & \multirow[t]{2}{*}{600} \\
\hline & & $\%$ & 20 & 56,7 & 20,8 & 2,5 & 0 & 100 & 41,17 & \\
\hline \multirow[t]{2}{*}{$A F 2$} & \multirow{2}{*}{$\begin{array}{l}\text { I find it easier to master } \\
\text { Betawi vocabulary than } \\
\text { Bahasa }\end{array}$} & $\mathrm{F}$ & 37 & 71 & 12 & 0 & 0 & 120 & 215 & \multirow[t]{2}{*}{600} \\
\hline & & $\%$ & 30,8 & 59,2 & 10 & 0 & 0 & 100 & 35,83 & \\
\hline \multirow[t]{2}{*}{$A F 3$} & \multirow{2}{*}{$\begin{array}{l}\text { Betawi is more useful } \\
\text { than Bahasa }\end{array}$} & $\mathrm{F}$ & 25 & 60 & 25 & 10 & 0 & 120 & 260 & \multirow[t]{2}{*}{600} \\
\hline & & $\%$ & 20,8 & 50 & 20,8 & 8,33 & 0 & 100 & 43,33 & \\
\hline \multirow[t]{2}{*}{$A F 4$} & \multirow{2}{*}{$\begin{array}{l}\text { By mastering the Betawi } \\
\text { language, my self-esteem } \\
\text { has increased }\end{array}$} & $F$ & 24 & 72 & 22 & 2 & 0 & 120 & 242 & \multirow[t]{2}{*}{600} \\
\hline & & $\%$ & 20 & 60 & 18,3 & 1,67 & 0 & 100 & 40,33 & \\
\hline \multirow[t]{2}{*}{$A F 5$} & \multirow{2}{*}{$\begin{array}{l}\text { It is easier for me to } \\
\text { understand information }\end{array}$} & $\mathrm{F}$ & 32 & 75 & 13 & 0 & 0 & 120 & 221 & \multirow[t]{2}{*}{600} \\
\hline & & $\%$ & 26,7 & 62,5 & 10,8 & 0 & 0 & 100 & 36,83 & \\
\hline
\end{tabular}




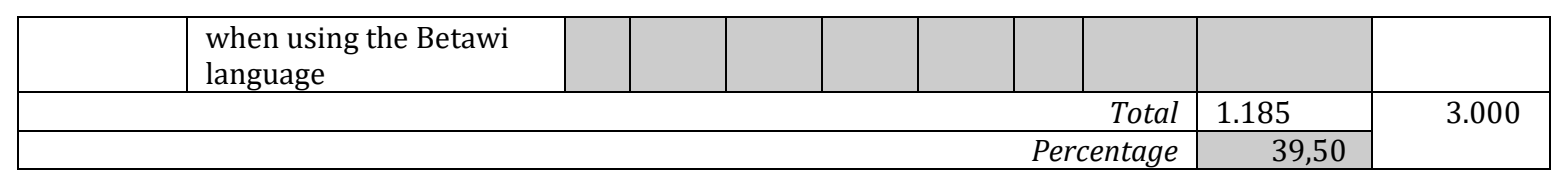

Table 2 shows that the expected score for respondents' answers to the questionnaire statement on affective aspects is 3,000 , with a total value of 1.185 or $39.50 \%$. All indicators are below 50\%, with the highest indicator score of AF3 at $43.33 \%$, which shows that Betawi is more useful than Bahasa. AF1 followed this at $41.17 \%$, which explains that respondents feel proud when communicating with the Betawi language. Therefore, based on the analysis results, respondents show negative language attitudes on the affective aspect, as seen from all indicators showing below $50 \%$. In the five indicators proposed in the affective aspect, the factors of pride, vocabulary mastery, and self-esteem are the lowest negative aspects. The affective aspect, which is the lowest compared to others, is associated with assessing whether adolescents feel proud of the Betawi language.

\section{Conative Aspects}

The following are the results of Betawi adolescents' attitudes towards their mother tongue from the conative aspect:

Table 3 Results of respondents' answers for Conative aspects

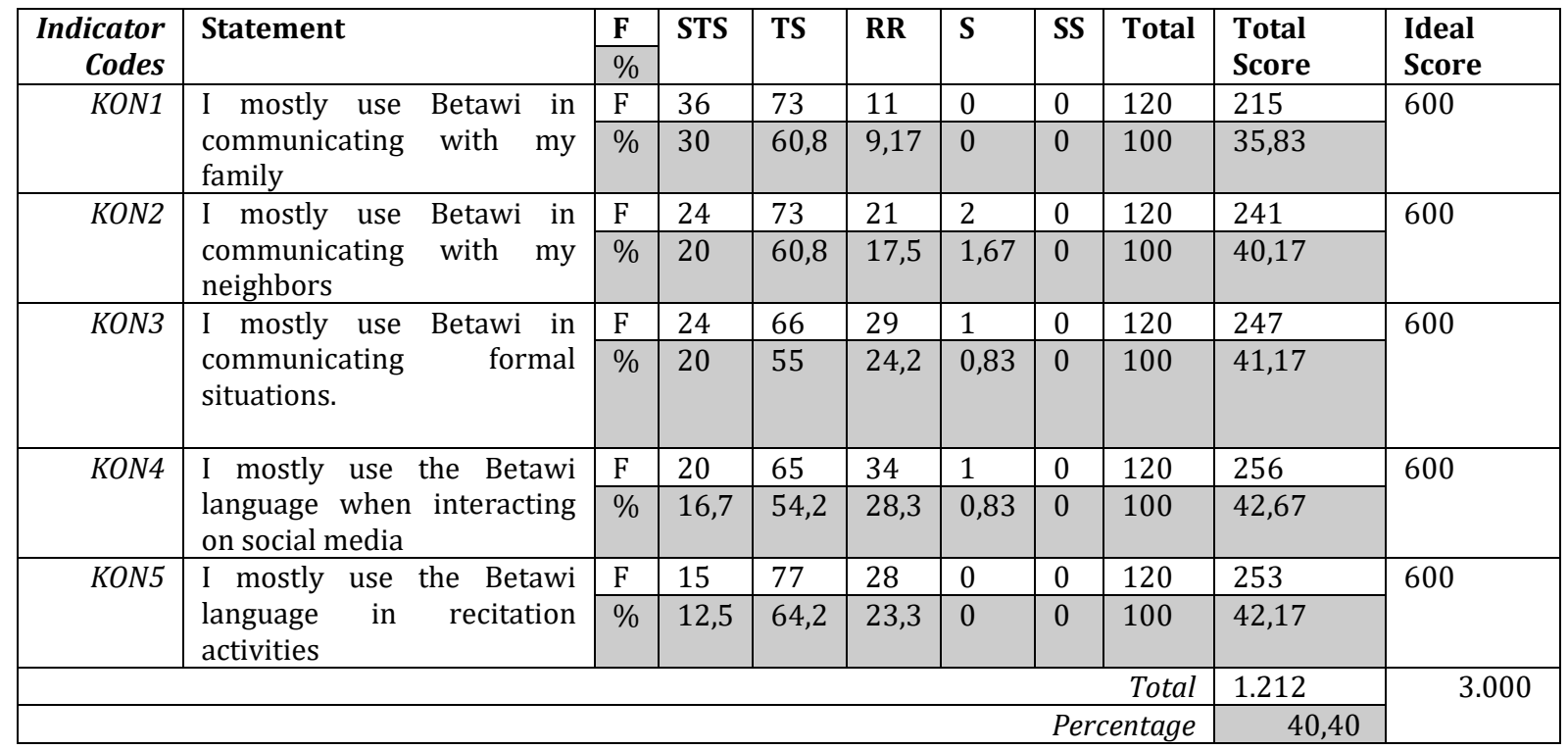


Table 3 shows that the expected score for respondents' answers to the questionnaire statement on the conative aspect is 3,000, with a total value of 1,212 or $40.40 \%$ of the ideal score. All indicators are below $50 \%$, and the highest score indicator is KON4 at $42.67 \%$, which shows that respondents use the Betawi Language more often when interacting in social media. Based on the analysis results, it is known that the respondents showed negative language attitudes on the conative aspect, as shown from all indicators below 50\%. The conative aspects regard behavior or action as the final decision of reactive readiness to use the Betawi language in every situation is negative. Generally, the three aspects of attitude are closely related, although pleasant or unpleasant experiences sometimes make the relationship incompatible. In this research, the relationship between the three aspects is in line, therefore it is predicted that behavior shows attitudes.

\section{The Influence of Bahasa on Shifting Their Mother Language}

Language shifting and preservation are like two sides of a coin, and this is based on other languages. Displaced language is incapable of defending itself with the conditions associated with long-term language choice of at least three generations and are collectively carried out by all citizens. The factors that promote language shift are economic, social, political, demographic, behavior, and community (Holmes, 2013). According to Sumarsono (2017), these factors are also attributed to bilingualism, migration, economy, and education. Durmuller and Gal (1980) reported that it comprises economics, religion, age, differences in prestige, and ambivalence. The following shows the research results on Betawi adolescent attitudes towards Bahasa language shifting on their mother tongue.

Table 4: Results of respondents' answers for variables of Bahasa

\begin{tabular}{|c|c|c|c|c|c|c|c|c|c|c|}
\hline $\begin{array}{r}\text { Indicator } \\
\text { Codes }\end{array}$ & Statement & $\begin{array}{l}\mathbf{F} \\
\%\end{array}$ & STS & TS & $\mathbf{R R}$ & $S$ & SS & Total & $\begin{array}{l}\text { Total } \\
\text { Score }\end{array}$ & $\begin{array}{l}\text { Ideal } \\
\text { Score }\end{array}$ \\
\hline \multirow[t]{2}{*}{ BHS1 } & \multirow{2}{*}{$\begin{array}{l}\text { Bahasa shows my } \\
\text { identity as the Bahasa }\end{array}$} & $\mathrm{F}$ & 3 & 7 & 24 & 77 & 9 & 120 & 442 & \multirow[t]{2}{*}{600} \\
\hline & & $\%$ & 2,5 & 5,83 & 20 & 64,2 & 7,5 & 100 & 73,67 & \\
\hline \multirow[t]{2}{*}{ BHS2 } & \multirow{2}{*}{$\begin{array}{l}\text { Bahasa as a means of } \\
\text { daily communication } \\
\text { in the family }\end{array}$} & $\mathrm{F}$ & 3 & 9 & 27 & 77 & 4 & 120 & 430 & \multirow[t]{2}{*}{600} \\
\hline & & $\%$ & 2,5 & 7,5 & 22,5 & 64,2 & 3,33 & 100 & 71,67 & \\
\hline \multirow[t]{2}{*}{ BHS3 } & \multirow{2}{*}{$\begin{array}{l}\text { The government is } \\
\text { preserving Bahasa } \\
\text { with concrete } \\
\text { programs }\end{array}$} & $\mathrm{F}$ & 5 & 15 & 30 & 63 & 7 & 120 & 412 & \multirow[t]{2}{*}{600} \\
\hline & & $\%$ & 4,17 & 12,5 & 25 & 52,5 & 5,83 & 100 & 68,67 & \\
\hline \multirow[t]{2}{*}{ BHS4 } & \multirow{2}{*}{$\begin{array}{l}\text { I feel proud when } \\
\text { communicating in } \\
\text { Bahasa }\end{array}$} & $\mathrm{F}$ & 0 & 10 & 36 & 64 & 10 & 120 & 434 & \multirow[t]{2}{*}{600} \\
\hline & & $\%$ & 0 & 8,33 & 30 & 53,3 & 8,33 & 100 & 72,33 & \\
\hline \multirow[t]{2}{*}{ BHS5 } & \multirow{2}{*}{$\begin{array}{l}\text { I find it easier to } \\
\text { master Bahasa } \\
\text { vocabulary than } \\
\text { Betawi }\end{array}$} & $\mathrm{F}$ & 0 & 13 & 46 & 57 & 4 & 120 & 412 & \multirow[t]{2}{*}{600} \\
\hline & & $\%$ & 0 & 10,8 & 38,3 & 47,5 & 3,33 & 100 & 68,67 & \\
\hline
\end{tabular}




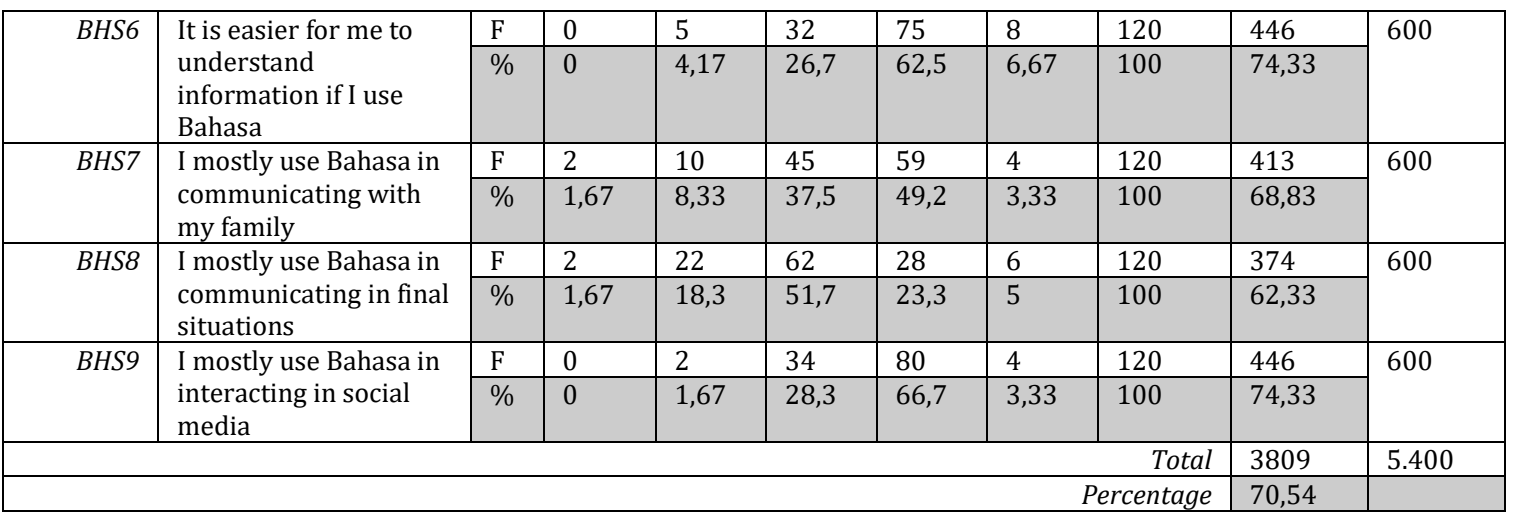

Table 4 shows that the expected score for respondents' answers to the questionnaire statement on Bahasa variables is 5,400, with a total value of 3,809 or $70.54 \%$ of the ideal score. The results indicate that most of the respondents agree that Bahasa has shifted their native language. The highest score indicators were BHS6 and BHS9 at $74.33 \%$, which shows that respondents find it easier to understand information and often use Bahasa to interact in social media.

\section{The Influence of Foreign Languages Shifts Their Mother Language}

Foreign languages also have the potential to shift the attitude of Betawi youth towards their mother tongue. This is due to teenagers' tendency in the capital to use it as a prestige, especially in schools, where it is taught as a compulsory subject. The following shows the research results on Betawi adolescent attitudes towards foreign languages shifting their mother tongue:

Table 5 Results of Respondents' Answers for Foreign Language Variables

\begin{tabular}{|c|c|c|c|c|c|c|c|c|c|c|}
\hline $\begin{array}{c}\text { Indicator } \\
\text { Codes }\end{array}$ & Statement & $\begin{array}{l}\mathbf{F} \\
\\
\end{array}$ & STS & TS & RR & $S$ & SS & Total & $\begin{array}{l}\text { Total } \\
\text { Score }\end{array}$ & $\begin{array}{l}\text { Ideal } \\
\text { Score }\end{array}$ \\
\hline \multirow[t]{2}{*}{$B A 1$} & \multirow{2}{*}{$\begin{array}{l}\text { Foreign languages show } \\
\text { my identity as a global } \\
\text { nation }\end{array}$} & $\mathrm{F}$ & 6 & 84 & 29 & 1 & 0 & 120 & 265 & \multirow[t]{2}{*}{600} \\
\hline & & $\%$ & 5 & 70 & 24,2 & 0,83 & 0 & 100 & 44,17 & \\
\hline \multirow[t]{2}{*}{$B A 2$} & \multirow{2}{*}{$\begin{array}{l}\text { Foreign language } \\
\text { vocabulary as a means of } \\
\text { daily communication in the } \\
\text { family }\end{array}$} & $\mathrm{F}$ & 5 & 72 & 35 & 8 & 0 & 120 & 286 & \multirow[t]{2}{*}{600} \\
\hline & & $\%$ & 4,17 & 60 & 29,2 & 6,67 & 0 & 100 & 47,67 & \\
\hline \multirow[t]{2}{*}{$B A 3$} & \multirow{2}{*}{$\begin{array}{l}\text { The government conducts } \\
\text { foreign language } \\
\text { preservation with real } \\
\text { programs }\end{array}$} & $\mathrm{F}$ & 6 & 52 & 53 & 9 & 0 & 120 & 305 & \multirow[t]{2}{*}{600} \\
\hline & & $\%$ & 5 & 43,3 & 44,2 & 7,5 & 0 & 100 & 50,83 & \\
\hline \multirow[t]{2}{*}{$B A 4$} & \multirow{2}{*}{$\begin{array}{l}\text { I feel proud when } \\
\text { communicating using } \\
\text { foreign language } \\
\text { vocabulary }\end{array}$} & $\mathrm{F}$ & 4 & 69 & 43 & 4 & 0 & 120 & 287 & \multirow[t]{2}{*}{600} \\
\hline & & $\%$ & 3,33 & 57,5 & 35,8 & 3,33 & 0 & 100 & 47,83 & \\
\hline$B A 5$ & & $F$ & 21 & 64 & 29 & 6 & 0 & 120 & 260 & 600 \\
\hline
\end{tabular}




\begin{tabular}{|c|c|c|c|c|c|c|c|c|c|c|}
\hline & $\begin{array}{l}\text { I find it easier to master } \\
\text { foreign language } \\
\text { vocabulary than Betawi } \\
\text { and Bahasa }\end{array}$ & $\%$ & 17,5 & 53,3 & 24,2 & 5 & 0 & 100 & 43,33 & \\
\hline \multirow[t]{2}{*}{$B A 6$} & \multirow{2}{*}{$\begin{array}{l}\text { It is easier for me to } \\
\text { understand information if I } \\
\text { use foreign language } \\
\text { vocabulary }\end{array}$} & $\mathrm{F}$ & 26 & 69 & 25 & 0 & 0 & 120 & 239 & \multirow[t]{2}{*}{600} \\
\hline & & $\%$ & 21,7 & 57,5 & 20,8 & 0 & 0 & 100 & 39,83 & \\
\hline \multirow[t]{2}{*}{$B A 7$} & \multirow{2}{*}{$\begin{array}{l}\text { I mostly use foreign } \\
\text { language vocabulary in } \\
\text { communicating with my } \\
\text { family }\end{array}$} & $\mathrm{F}$ & 19 & 74 & 27 & 0 & 0 & 120 & 248 & \multirow[t]{2}{*}{600} \\
\hline & & $\%$ & 15,8 & 61,7 & 22,5 & 0 & 0 & 100 & 41,33 & \\
\hline \multirow[t]{2}{*}{$B A 8$} & \multirow{2}{*}{$\begin{array}{l}\text { I mostly use foreign } \\
\text { language vocabulary in } \\
\text { communicating formal } \\
\text { situations }\end{array}$} & $\mathrm{F}$ & 9 & 77 & 24 & 7 & 3 & 120 & 278 & \multirow[t]{2}{*}{600} \\
\hline & & $\%$ & 7,5 & 64,2 & 20 & 5,83 & 2,5 & 100 & 46,33 & \\
\hline \multirow[t]{2}{*}{$B A 9$} & \multirow{2}{*}{$\begin{array}{l}\text { I mostly use foreign } \\
\text { language vocabulary when } \\
\text { interacting on social media }\end{array}$} & $\mathrm{F}$ & 4 & 77 & 27 & 9 & 3 & 120 & 290 & \multirow[t]{2}{*}{600} \\
\hline & & $\%$ & 3,33 & 64,2 & 22,5 & 7,5 & 2,5 & 100 & 48,33 & \\
\hline & & & & & & & \multicolumn{2}{|r|}{ Total } & 2458 & 5.400 \\
\hline & & & & & & & & centage & 45,52 & \\
\hline
\end{tabular}

Table 5 ideally shows that the expected score for respondents' answers to the questionnaire statement on foreign language variables is 5,400 , with a total value of 2.458 or $45.52 \%$ of the ideal score. The results indicate that a small proportion of respondents agree that foreign languages affect shifting their mother tongue.

\section{Descriptive Statistics Test Results}

Table 6 Descriptive Statistics

\begin{tabular}{|l|c|c|c|c|c|}
\hline & N & Minimum & Maximum & Mean & Std. Deviation \\
\hline Attitude & 120 & 1.00 & 3.27 & 2.0253 & .49546 \\
\hline Bahasa & 120 & 1.78 & 4.89 & 3.5273 & .52200 \\
\hline Foreign language & 120 & 1.33 & 3.56 & 2.2760 & .47831 \\
\hline Valid N (listwise) & 120 & & & & \\
\hline
\end{tabular}

The descriptive statistical test results in Table 6 show that the attitude variable has a maximum, maximum, and average values of $3.27,1.00$, and f 2.0253 . It shows that the language attitudes of Betawi adolescents towards their mother tongue are negative. This is also seen from the answers to the questionnaire in which most respondents disagree or have negative attitudes towards the Betawi language. The variable of Betawi adolescent attitudes towards the ability to Bahasa to shift their mother tongue 
has maximum, maximum, and average values of $4.89,1.78$, and 3.5273 . It shows that Bahasa can shift their mother tongue, as indicated by the questionnaire's answers in which most of the respondents agreed. The variable of Betawi adolescent attitudes towards foreign languages shifting their mother tongue has maximum, maximum, and average values of $3.56,1.33$, and 2.2760 . This means that foreign languages do not affect shifting their mother tongue, as indicated by the questionnaire's answers in which most respondents did not agree.

\section{Conclusion}

The research results on Betawi adolescents' language attitudes towards their mother tongue were negative in all aspects. The cognitive, affective, and conative aspects have values of $41.63 \%, 39.50 \%$, and $40.40 \%$ of the ideal score. Furthermore, Betawi adolescents' attitude towards the influence of Bahasa shifting their mothertongue shows a positive attitude with no effect, as indicated by $70.54 \%$. Finally, Betawi adolescents' attitude towards the influence of foreign languages shifting their mothertongue shows a negative attitude with an effect as indicated by $45.52 \%$ ) of respondents.

\section{References}

Abdurrahman, A. (2011). Sosiolinguistik: Teori, Peran, Dan Fungsinya Terhadap Kajian Bahasa Sastra. LiNGUA: Jurnal Ilmu Bahasa Dan Sastra, 3(1), 18-37. https://doi.org/10.18860/ling.v3i1.571

Coluzzi, P. (2011). Majority and minority language planning in Brunei Darussalam. Language Problems and Language Planning, 35, 222-240.

Ezhevskaya, A. (2020). Insights from sociolinguistics and translation studies for maintaining bilingualism in the home. Missiology, 48(4), 410-421. https://doi.org/10.1177/0091829620910188

Ferguson, G. (2019). The Palgrave handbook of minority languages and communities. Journal of Multilingual and Multicultural Development, 41, 649-652.

Giyoto. (2013). Pengantar Sosiolinguistik. Perpustakaan Nasional: Katalog Dalam Terbitan (KDT), 1(1), 1-133.

Hogan-Brun, G., \& o_Rourke, B. (2019). The Palgrave Handbook of Minority Languages and Communities.

Leach, H., Watson, K., \& Gnevsheva, K. (2016). Perceptual dialectology in northern England: Accent recognition, geographical proximity and cultural prominence. 
Journal of Sociolinguistics, 20, 192-211.

Leng, L. Y. (1980). Race, Language, and National Cohesion in Southeast Asia. Journal of Southeast Asian Studies, 11 , 122-138. https://doi.org/DOI:10.1017/S0022463400019020

Marten, H. F., Mensel, L. V, \& Gorter, D. (2012). Studying Minority Languages in the Linguistic Landscape.

Mu'in, F. (2019). SOCIOLINGUISTICS: A Language Study in Sociocultural Perspemctives. Pendidikan Bahasa, Jurusan Fkip, Seni Banjarmasin, Ulm. http://eprints.ulm.ac.id/7174/1/0 1 Sociolinguistics A Language Study in Sociocultural Perspectives.pdf

Muniandy, M. K., Nair, G. K. S., Shanmugam, S. K. K., Ahmad, I., \& Noor, N. B. M. (2010). Sociolinguistic Competence and Malaysian Students' English Language Proficiency. English Language Teaching, 3(3), 145-151. https://doi.org/10.5539/elt.v3n3p145

Partala, T., \& Kallinen, A. (2012). Understanding the most satisfying and unsatisfying user experiences: Emotions, psychological needs, and context. Interacting with Computers, 24, 25-34. https://doi.org/10.1016/j.intcom.2011.10.001

Sercombe, P. (2019). Minorities, Languages, Education, and Assimilation in Southeast Asia. https://doi.org/DOI:10.1057/978-1-137-54066-9_15

Slobodaniuc, A. (2021). The Sociolinguistic Dimension In The Teaching, Learning And Assessment Of Verbal Communication Competence In French For Specific Purposes, Moldova State University, Republic of Moldova. Scientific Collection 'Interconf,' 47(1), 45-55. https://ojs.ukrlogos.in.ua/index.php/interconf/article/view/10561/9920

Tanasy, N. (2019). Varian Bahasa dan Kohesi Sosial : Studi Kasus Komunitas KOSEMA di Kedai Kita Makassar. Jurnal Emik, 2(1).

Abdurrahman, A. (2011). Sosiolinguistik: Teori, Peran, Dan Fungsinya Terhadap Kajian Bahasa Sastra. LiNGUA: Jurnal Ilmu Bahasa Dan Sastra, 3(1), 18-37. https://doi.org/10.18860/ling.v3i1.571

Coluzzi, P. (2011). Majority and minority language planning in Brunei Darussalam. Language Problems and Language Planning, 35, 222-240.

Ezhevskaya, A. (2020). Insights from sociolinguistics and translation studies for maintaining bilingualism in the home. Missiology, 48(4), 410-421. https://doi.org/10.1177/0091829620910188

Ferguson, G. (2019). The Palgrave handbook of minority languages and communities. Journal of Multilingual and Multicultural Development, 41, 649-652.

Giyoto. (2013). Pengantar Sosiolinguistik. Perpustakaan Nasional: Katalog Dalam Terbitan (KDT), 1(1), 1-133. 
Hogan-Brun, G., \& o_Rourke, B. (2019). The Palgrave Handbook of Minority Languages and Communities.

Leach, H., Watson, K., \& Gnevsheva, K. (2016). Perceptual dialectology in northern England: Accent recognition, geographical proximity and cultural prominence. Journal of Sociolinguistics, 20, 192-211.

Leng, L. Y. (1980). Race, Language, and National Cohesion in Southeast Asia. Journal of Southeast Asian Studies, 11, 122-138. https://doi.org/DOI:10.1017/S0022463400019020

Marten, H. F., Mensel, L. V, \& Gorter, D. (2012). Studying Minority Languages in the Linguistic Landscape.

Mu'in, F. (2019). SOCIOLINGUISTICS: A Language Study in Sociocultural Perspemctives. Pendidikan Bahasa, Jurusan Fkip, Seni Banjarmasin, Ulm. http://eprints.ulm.ac.id/7174/1/0 1 Sociolinguistics A Language Study in Sociocultural Perspectives.pdf

Muniandy, M. K., Nair, G. K. S., Shanmugam, S. K. K., Ahmad, I., \& Noor, N. B. M. (2010). Sociolinguistic Competence and Malaysian Students' English Language Proficiency. English Language Teaching, 3(3), 145-151. https://doi.org/10.5539/elt.v3n3p145

Partala, T., \& Kallinen, A. (2012). Understanding the most satisfying and unsatisfying user experiences: Emotions, psychological needs, and context. Interacting with Computers, 24, 25-34. https://doi.org/10.1016/j.intcom.2011.10.001

Sercombe, P. (2019). Minorities, Languages, Education, and Assimilation in Southeast Asia. https://doi.org/DOI:10.1057/978-1-137-54066-9_15

Slobodaniuc, A. (2021). The Sociolinguistic Dimension In The Teaching, Learning And Assessment Of Verbal Communication Competence In French For Specific Purposes, Moldova State University, Republic of Moldova. Scientific Collection 'Interconf,' 47(1), 45-55. https://ojs.ukrlogos.in.ua/index.php/interconf/article/view/10561/9920

Tanasy, N. (2019). Varian Bahasa dan Kohesi Sosial : Studi Kasus Komunitas KOSEMA di Kedai Kita Makassar. Jurnal Emik, 2(1). 